\title{
Preface to the fifth edition
}

The fifth edition builds upon the earlier editions while maintaining the aim of providing a comprehensive analysis of the UK financial system.

The early part of the twenty-first century has witnessed a sea-change in regulation of the financial system following the financial crisis of 2007-8. Prior to that financial crisis, the official policy was directed to deregulating the financial system, whereas after 2008 the move is towards increased regulation. This has caused changes in the nature and behaviour of the institutions and the regulatory authorities, with the result that many texts quickly became dated. The aim of this book is to bring the discussion right up to date. Major changes to the contents of the fourth edition therefore include the following:

(i) The chapters on retail and wholesale banking have been compressed into a single chapter dealing with the new classification of 'monetary financial institutions'. Within this chapter consideration is given to additional topics such as the report of the Independent Commission on Banking (the Vickers report), narrow banking and Islamic banking.

(ii) The chapter on investment institutions is expanded to include the new investment vehicles and the shadow banking system.

(iii) Discussion of the role of the central bank has been enhanced to include the development of new policy measures such as quantitative easing and the new techniques adopted by the Bank of England for intervention in the London money markets.

(iv) The material on markets in general has been expanded to include more detail on electronic trading in general and of high-speed trading in particular. In addition, consideration is given to short selling and the mechanics of markets ('plumbing' in the literature).

(v) The treatment of regulation has been expanded considerably. The causes of the 2007-8 financial crisis are discussed as a prelude to consideration of regulation, which is split into two chapters. The first covers the changes to banking regulation in the last decade and 
the second to regulation of other financial institutions. This involves examination of regulation emanating both from within the UK and also from supranational bodies such as the Bank for International Settlements and the European Union.

(vi) The concluding chapter now provides a critique of the value of finance and financial innovation to the economy as a whole.

In addition to these major changes, each chapter has been updated to reflect current practices.

We have also changed the structure of the book, which is now presented in three parts plus introductory and concluding chapters supplemented by a comprehensive glossary. The three main sections cover: financial institutions; financial markets; and regulation of banks and other financial institutions. The advantage of this structure is that the book can be used for a full course on the UK financial system or for the individual components on a modular basis. Each chapter contains comprehensive statistics to supplement the narrative.

The effects of UK's decision to leave the European Union ('Brexit') in June 2016 are likely to be felt by the UK financial system in two directions: regulation and operations. As far as bank regulation is concerned we do not think Brexit will make much, if any, difference to the substance of regulation of banks (chapter 15). While the proximate source of regulation of banks stems from the EU, the original source is the Basel Committee on Banking Supervision (BCBS). Membership of the committee is widely based and includes representation of the EU and UK. The regulation of the financial institutions other than banks (discussed in chapter 16) originates more from the EU and is consequently more likely to change.

Turning now to the effect of Brexit on the operations of the UK financial system, the consequences are likely to be significant in the long run but are not predictable at the time of writing. Essentially the UK will have to negotiate some other relationship with the EU, like that of Norway (in the European Economic Area) or Switzerland (in the European Free Trade Association). However, at present the EEA and EFTA do not cover passporting - the arrangements that allow a financial services firm to operate throughout the EU based on its authorisation in the UK.

Apart from the Brexit shock, the UK financial system is very dynamic and is subject to frequent changes both in its structure and in the services it provides. It is also to subject to changes in the environment in which it operates, such as a change in legislation. Thus it is important that the interested reader keeps abreast of future changes by reading the financial pages of the quality press and publications by such bodies as the Bank of England and the Bank for International Settlements.

Finally, our thanks go to Professor Kent Matthews of Cardiff University, Jason Laws of the University of Liverpool and Richard Harrington of 
the University of Manchester for helpful discussion at different stages of producing this text. Our thanks also go to August Wang for computational assistance and Ralph Footring for copy-editing assistance during preparation of the manuscript. All errors remain our responsibility. 
Mike Buckle and John Thompson - 9781526153692 Downloaded from manchesterhive.com at $04 / 26 / 2023$ ๑8:17:18AM via free access 